\title{
Investigation and Analysis on Electromagnetic Radiation from Cellular Base Station Transmitters and the Implications to Human Body
}

\author{
Opara K. Felix \\ Department of Electrical and Electronic Engineering, Federal University of Technology \\ P.M.B. 1526 Owerri, Nigeria \\ E-mail: kefelop@yahoo.com
}

Adigwe U. Gabriel

Department of Electrical and Electronic Engineering, Federal University of Technology

P.M.B. 1526 Owerri, Nigeria

E-mail: Uche270@yahoo.com

Agbaraji C. Emmanuel (Corresponding author)

Department of Electrical and Electronic Engineering, Federal University of Technology

P.M.B. 1526 Owerri, Nigeria

E-mail: wattchux@yahoo.com

Received: April 10, 2013 Accepted: May 8, $2013 \quad$ Published: June 15, 2014

doi:10.5296/jee.v5i1.4999ＵRL: http://dx.doi.org/10.5296/jee.v5i1.4999

\begin{abstract}
Electromagnetic Radiation (EMR) is a form of energy emitted and absorbed by charged particles which can be harmful to human body depending upon the radiated power density and the distance from the transmitter. This paper investigates the implications of EMR from the mobile cellular Base Station (BS) transmitter to the body. A cellular mobile network analyzer which can measure power density of a cellular mobile signal was used to measure
\end{abstract}




\section{Macrothink}

the received power density from the BS transmitter in two scenarios: along the express road and residential/commercial area. The radiated power absorbed was calculated to be $348.94 \mathrm{nW} / \mathrm{cm} 2$ at $210 \mathrm{~m}$ distance from transmitter and higher as moved closer to the transmitter. It was concluded from the results that the power density measured within $300 \mathrm{~m}$ distance from BS transmitters is of higher and negative health concern. We therefore recommend that the government should develop a strict policy to ensure that the power density radiated is reduced generally and BS transmitters should be located from $300 \mathrm{~m}$ to $500 \mathrm{~m}$ distance from human residence.

Keywords: EMR, BS Transmitter, Distance, Frequency, Power Density, ill-Health, Radiation 


\section{Introduction}

Electromagnetic Field (EMF) and waves are an important and main media to carry signals from a certain source to the desired destination; this signal can be voice, data or image (Mousa, 2011). The EMF is propagating at the speed of light in free space $(300,000 \mathrm{~km} / \mathrm{s})$ so it can be modulated, transmitted and received while conveying the necessary information (Mohana, 2002; Jon, 2003; Theodore, 2002). EMR is a form of energy emitted and absorbed by charged particles, which exhibits wave-like behaviour as it travels through space (Wikipedia, 2012). The effects of EMR (Wiki, 2014) upon biological systems depend both upon the radiation's power and frequency. For lower frequencies of EMR up to those of visible light (i.e., radio, microwave, infrared), the damage done to cells and also to many ordinary materials under such conditions is determined mainly by heating effects, and thus by the radiation power. By contrast, for higher frequency radiations at ultraviolet frequencies and above (i.e., X-rays and gamma rays) the damage to chemical materials and living cells by EMR is far larger than that done by simple heating, due to the ability of single photons in such high frequency EMR to damage individual molecules chemically (Wikipedia, 2012).

Cell phone technology has revolutionized the telecommunication scenario in the world and more especially in the developing nations. Due to its several advantages especially in the increasing number of application benefits, cell phone technology has grown exponentially in the last decade. One could chat with relatives, school mates, colleagues etc from home or any place, watch real-time events, listen to radio and music, pay for goods and services, read books and online news, monitor and control processes and many more using the cell phone. In 2010, some estimates stated that there were more than 50 million cell phone users and nearly 4.4 thousand cell phone towers to meet the communication demand (Girish, 2010). Currently the number has increased tremendously due to the reduced price of the cell phones and its portability. Every home is recording at least one cell phone per person; kids in primary and secondary schools are allowed to have their phones with them especially in some developing countries such as Nigeria because of security reasons. As a result, the number of cell towers has also increased tremendously in order to provide adequate service to the cell phone users. The cell towers are randomly situated in every place in countries such as Nigeria; some are located right inside peoples' homes, very close to churches, schools, market places, offices etc. In most developing countries, every major mobile service provider would like to erect its cell tower in a particular area with others to serve the users using their networks. The number of cell phones and cell towers keep on increasing exponentially without giving due consideration to its disadvantages especially to the human users and the environment. All over the world, people mostly researchers have been debating about associated health risk due to radiation from cell phone and cell tower. While some are saying that there exists little or no health effect from the cell phone technology due to either lack of proper knowledge or business inclinations, others are stating with facts the huge and disastrous health effect of the technology to mankind.

Every cell phone has a SAR (Specific Absorption Rate) rating which has a limit of $1.6 \mathrm{~W} / \mathrm{Kg}$ and it is calculated to be 6 minutes (360 seconds) per day usage for a person. Considering the SAR limit, a person should not make use of cell phone for more than 24 minutes (1440 
seconds) per day following the safety standards. Unfortunately, majority of the cell phone users do not have this information, as a result many people make cell phone calls for more than an hour in a day without knowing the health damage related with this issue.

A cell phone base station (Mousa, 2011) and its transmitting power are designed in such a way that mobile phone should be able to transmit and receive enough signal for proper communication up to a few kilometers. Majority of these towers are mounted near the residential and office buildings to provide good mobile phone coverage to the users. These cell towers work 24 hours per day and so transmit radiation 24 hour per day, and the people living within the radius of $10 \mathrm{~s}$ of meters from the tower will receive 10,000 to $10,000,000$ times stronger signal than required for mobile communication (Girish, 2010). In countries such as India, Nigeria and other developing nations, millions of people reside within these high radiation zones without knowing the possible harm the radiation from the transmitters can cause to the human body.

\section{Literature Review}

The effect of mobile phone radiation on human health is the subject of recent interest and study, as a result of the enormous increase in mobile phone usage throughout the world (Wiki, 2014). Mobile phones use electromagnetic radiation in the microwave range. Koprivica (2013) opined that as a result of dense installations of public mobile base station, additional electromagnetic radiation occurs in the living environment. Kovach (2007), complained that exposure to EMR is growing and becoming a serious health threat. He also pointed out the huge public health crisis looming from one particular threat: EMR from cellular phones, both the radiation from the handsets and from the tower-based antennas carrying the signals which studies have linked to development of brain tumours, genetic damage, and other exposure-related conditions (Kovach, 2007). Part of the radio waves emitted by a mobile telephone handset is absorbed by the body (Wiki, 2014).

\subsection{Previous Work on Radiation Measurement}

FU et al (2010) measured the status quo of the level of Indoor Electromagnetic Radiation (IER), on which further epidemiological investigation on the relation between the level of IER and certain health effects could be based. Halim et al (2009) carried out radiation measurements with a Geiger-Mueller LND712 detector, Radiation Alert Monitor 4, calibrated by Cesium 137 every month during one year in order to detect natural background radiation rate exposed by man around base station. Sabah (2013) in a study carried out measurements at various places near the cell towers inside residential areas in Kirkuk-Iraq and found that the radiation levels were above the recommended values.

In France, Santini et al (2002) in their study observed that the people who lived closest to the cellular antennas had the highest incidences of the following disorders: fatigue, sleep disturbances, headaches, feeling of discomfort, and difficulty in concentrating, depression, memory loss, visual disruptions, irritability, hearing disruptions, skin problems, cardiovascular disorders, and dizziness. Eger et al (2004), examined in Germany whether people living close to cellular transmitter antennas were exposed to a greater risk of 
becoming ill with malignant tumors. Wolf and Wolf (2004) presented in Israel that, based on medical records of people living within 350 meters of a long established phone mast, showed a fourfold increased incidence of cancer compared with the general population of Israel, and a tenfold increase specifically among women, compared with the surrounding locality further from the mast. Oberfeld (2004) in Spain found in a study significant ill-health effects among those living in the vicinity of two GSM mobile phone base stations: he found out that depressive tendency, fatigue, sleeping disorder, difficulty in concentration and cardiovascular problems were the strongest five associations. People living within 50 to 300 meter radius as illustrated in figure 1, are in the high radiation zone and are more prone to ill-effects of electromagnetic radiation.

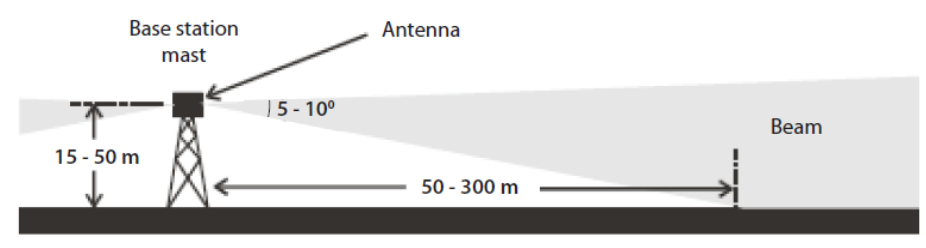

Figure 1. Direction of coverage due to a base station antenna (Mousa, 2011)

\subsection{Electromagnetic Radiation Models}

Power density is defined as the power per unit area normal to the direction of propagation usually expressed in units of Watts per square meter $\left(\mathrm{W} / \mathrm{m}^{2}\right)$, or for convenience in units such as milliwatts per square meter $\left(\mathrm{mW} / \mathrm{m}^{2}\right)$, or even in microwatts per square centimeter $\left(\mu \mathrm{W} / \mathrm{cm}^{2}\right)$. Sources of electromagnetic energy (Liu et al, 2008), range from man-made sources such as commercial broadcast stations and automobile ignition systems to natural sources such as galactic noise and lightning. Considering the signal transmission from cell towers, Power density $\mathrm{P}_{\mathrm{d}}$ at a distance $\mathrm{R}$ is given by (Girish, 2010; Sujoy, 2011):

$\mathrm{P}_{\mathrm{d}}=\left(\frac{p_{\mathrm{r}} \times G_{\mathrm{f}}}{4 \pi R^{2}}\right) \mathrm{Watt} / \mathrm{m}^{2}$

Where, $\mathrm{P}_{\mathrm{t}}=$ Transmitter power in Watts, $\mathrm{G}_{\mathrm{t}}=$ Gain of Transmitting antenna, $\mathrm{R}=$ Distance from the transmitting antenna in meters.

Power received $\mathrm{P}_{\mathrm{r}}$ by an antenna at a distance $\mathrm{R}$ is given by:

$\mathrm{P}_{\mathrm{r}}=\left(\frac{B_{\mathrm{r}} \times G_{\mathrm{i}} \times A r e a}{4 \pi R^{2}}\right) \mathrm{Watt} / \mathrm{m}^{2}$

$\operatorname{Pr}=P_{d} \times$ Areu Watt $/ \mathrm{m}^{2}$

Power absorbed by human body can be calculated using the equations 2 and 3 and the human body area is measured as illustrated in figure 2 and the distance from the cell tower is also measured as shown in figure 1. 


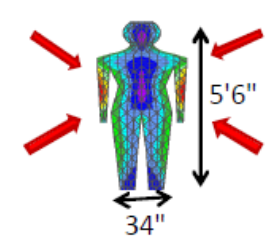

Figure 2. Human body measurement (Girish, 2010)

\subsection{Radiation Norms}

The radiation norms adopted in some countries such as India is given by ICNIRP guidelines (ICNIRP, 1998) of 1998 for safe power density of $\mathrm{f} / 200$, where frequency (f) is in MHz. Thus, for GSM900 transmitting band (935-960 MHz), power density is $4.7 \mathrm{~W} / \mathrm{m}^{2}$ and for GSM1800 transmitting band $(1810-1880 \mathrm{MHz})$, it is $9.2 \mathrm{~W} / \mathrm{m}^{2}$. In the same vein, based on the recommendations of an Inter Ministerial Committee constituted by DoT in the year 2010, limiting reference levels of Electromagnetic Radiation from Mobile towers is reduced to $1 / 10^{\text {th }}$ of the limit prescribed by the ICNIRP with effect from September 1, 2012 (Rakesh, 2013) as shown in table 1.

Table 1. Recommended Radiation Norms (Rakesh, 2013)

\begin{tabular}{|l|l|l|}
\hline Frequency & ICNIRP Radiation Norms & $\begin{array}{l}\text { Revised DoT Norms } \\
\text { Effective from 01/09/2012 }\end{array}$ \\
\hline $900 \mathrm{MHz}$ & $4.5 \mathrm{Watt} / \mathrm{Sqm}$ & $0.45 \mathrm{Watt} / \mathrm{Sqm}$ \\
\hline $1800 \mathrm{MHz}$ & $9.0 \mathrm{Watt} / \mathrm{Sqm}$ & $0.90 \mathrm{Watt} / \mathrm{Sqm}$ \\
\hline $2100 \mathrm{MHz}$ & $10.5 \mathrm{Watt} / \mathrm{Sqm}$ & $1.05 \mathrm{Watt} / \mathrm{Sqm}$ \\
\hline
\end{tabular}

Considering the ICNIRP guidelines (ICNIRP, 1998), for simultaneous exposure to multiple frequency fields, the sum of all the radiation in a particular environment must be taken into consideration. Hence, the sum of the all the radiation from a base station mast serving two or more service providers' signal transmission must also be considered. Bio-Initiative report (Girish, 2010; Sujoy, 2011) in 2007 suggested some of the proposed maximum exposure values.

i. Less than $0.1 \mu \mathrm{W} / \mathrm{m}^{2}\left(0.00001 \mu \mathrm{W} / \mathrm{cm}^{2}\right)$ - no health concern

ii. $0.1-10 \mu \mathrm{W} / \mathrm{m}^{2}\left(0.00001\right.$ to $\left.0.001 \mu \mathrm{W} / \mathrm{cm}^{2}\right)$ - slight health concern

iii. 10 - $1000 \mu \mathrm{W} / \mathrm{m}^{2}\left(0.001\right.$ to $\left.0.1 \mu \mathrm{W} / \mathrm{cm}^{2}\right)$ - severe health concern

iv. Greater than $1000 \mu \mathrm{W} / \mathrm{m}^{2}$ (greater than $0.1 \mu \mathrm{W} / \mathrm{cm}^{2}$ ) - extreme health concern

At many places in Nigeria, cell phone towers are mounted on the roof top of residential, commercial buildings especially banks, university office blocks etc. The radiation from multiple phones should be considered as well since many people have two or more phones on them as they walk about. It was recommended that safe power limit is $50 \mu \mathrm{W} / \mathrm{m}^{2}$ with upper limit as $100 \mu \mathrm{W} / \mathrm{m}^{2}$. However, these power limits have not been adequately made public nor 
put into consideration by the regulatory bodies in most developing countries such as Nigeria to monitor and strictly address the issue of high radiation levels which has become a global health issue.

\section{Methodology}

In order to study the cellular mobile radio signal propagation characteristic from the transmitters, two distinct scenarios were chosen. The first scenario consisted of cells of base stations in open areas along the high way connecting two major cities where buildings are far located. The objective was to study the level of received signal power as the receiver was conveyed away from the base station transmitter on a vehicle. The second scenario comprised of cells in areas inside a busy city where residential and business buildings of different heights are located. The objective was to study the level of received signal strength in the buildings that are very close to the base stations. Experimental measurements were collected in the first and second scenarios with the use of a cellular mobile network analyzer (Model Sagem 0T160) capable of measuring received signal power in decibel milli-watts (dBm).

\subsection{Description of Cell phone BS Transmitters and the Scenarios}

\section{First Scenario}

Cell-A and Cell-B transmitter antennas are vertical dipoles fixed at different heights on a metal tower depending on the location of the base station and the nature or arrangement of the buildings they are providing their services. Their specifications and properties are as stated in tables 2, 3 and 4 below:

Table 2. Cell-A transmitter antenna Base Station

\begin{tabular}{|l|l|}
\hline Height $\left(\mathrm{H}_{\mathrm{t}}\right)$ & $32 \mathrm{~m}$ \\
\hline Transmitting at frequencies $(\mathrm{fc})$ & $900 / 1800 \mathrm{Mz}$ \\
\hline Radiated power $\left(\mathrm{P}_{\mathrm{T}}\right)$ & $46 \mathrm{dBm}$ \\
\hline Transmitting antenna gain $\left(\mathrm{G}_{\mathrm{T}}\right)$ & $18 \mathrm{dBi}$ \\
\hline Effective Isotropic Radiated Powers (EIRP) & $64 \mathrm{dBm}$ \\
\hline Minimum received power for link $\left(\mathrm{R}_{\mathrm{m}}\right)$ & $102 \mathrm{dBm}$ \\
\hline
\end{tabular}

Table 3. Cell-B transmitter antenna Base Station (Located at highway)

\begin{tabular}{|l|l|}
\hline Height $\left(\mathrm{H}_{\mathrm{t}}\right)$ & $33 \mathrm{~m}$ \\
\hline Transmitting at frequencies $(\mathrm{fc})$ & $900 / 1800 \mathrm{Mz}$ \\
\hline Radiated power $\left(\mathrm{P}_{\mathrm{T}}\right)$ & $47 \mathrm{dBm}$ \\
\hline Transmitting antenna gain $\left(\mathrm{G}_{\mathrm{T}}\right)$ & $17.5 \mathrm{dBi}$ \\
\hline Effective Isotropic Radiated Powers (EIRP) & $64.5 \mathrm{dBm}$ \\
\hline Expected minimum received power for link $\left(\mathrm{R}_{\mathrm{m}}\right)$ & $104 \mathrm{dBm}$ \\
\hline
\end{tabular}


Table 4. / Cell-B transmitter antenna Base Station (Located inside the city)

\begin{tabular}{|l|l|}
\hline Height $\left(\mathrm{H}_{\mathrm{t}}\right)$ & $28 \mathrm{~m}$ \\
\hline Transmitting at frequencies $(\mathrm{fc})$ & $900 / 1800 \mathrm{Mz}$ \\
\hline Transmitting antenna gain $\left(\mathrm{G}_{\mathrm{T}}\right)$ & $17.5 \mathrm{dBi}$ \\
\hline Radiated power $\left(\mathrm{P}_{\mathrm{T}}\right)$ & $47 \mathrm{dBm}$ \\
\hline Effective Isotropic Radiated Powers (EIRP) & $64.5 \mathrm{dBm}$ \\
\hline Expected minimum received power for link $\left(\mathrm{R}_{\mathrm{m}}\right)$ & $104 \mathrm{dBm}$ \\
\hline
\end{tabular}

The signal power measuring equipment was conveyed on a vehicle with varied velocity of about $20-50 \mathrm{Kmhr}^{-1}$. During measurement, the readings of receiver signal power were taken as the vehicle moved away from the selected base station.

\subsection{Second Scenario}

In this scenario, measurement of receiver power and the respective distances were taken at various points within the premises of the resident and commercial buildings moving from the base station in the city. This area was chosen because of the closeness of the buildings to the transmitting base stations. The readings were taken over a period of two hours at 20 minutes intervals and repeated for three days.

\subsection{Determination of the Absorbed Power (Radiation)}

Electromagnetic radiation is measured as power density in units of milliwatts per square centimetre $\left(\mathrm{mW} / \mathrm{cm}^{2}\right)$ which is essentially the rate of energy flow per unit area (CCOHS, 2012). The received signal powers were recorded in decibel-miliwat $(\mathrm{dBm})$ with the respective distances in meters $(\mathrm{m})$ from the transmitting tower. However, the received signal powers detected by the measuring instrument at various distances are the power densities at those distances from the transmitting tower. To determine the power received (Radiation) by the human body living or passing within the mobile cellular signal network of a particular transmitting tower, the area of the human body as an object measured in centimetre square $\left(\mathrm{cm}^{2}\right)$ was considered. The radiation level absorbed by the body is calculated (Girish, 2010).

$\mathrm{P}_{\mathrm{rad}}=\boldsymbol{P}_{r} \times$ Area Watt $/ \mathrm{cm}^{2}$

Where, $\mathrm{P}_{\mathrm{rad}}=$ Power absorbed by body (Radiation level), $\mathrm{P}_{\mathrm{r}}=$ Power received

To determine the relationship between the measured received signal power and the distance, graph of the received signal power was plotted against the respective distances measured from the base station transmitters for the two cell types, Cell-A and Cell-B in the two senerios. Radiation levels absorbed by the body in the two scenarios were calculated with respect to the received power measured at a distance from the transmitter.

An interview/questionnaire was carried out with 20 (twenty) people seen living within 300 meters from the base station transmitters. The questions put to them were based on the possible illnesses likely to be caused by the electromagnetic radiations. 


\section{Mll Macrothink}

\section{Results and Analysis}

Absolute power of a signal is measured in wattage. The bel or decibel system can only describe relative power. The standard for transmitted signal radiation measurement is in $\mathrm{Wcm}^{2}$ or $\mathrm{mWcm}^{2}$ or $\mathrm{nWcm}^{2}$. Figures 3 to 6 illustrate the graph of received power density against distance.

$1 \mathrm{dBm}=0.001258925 \mathrm{~W}, 1 \mathrm{~W}=1,000,000,000 \mathrm{nW}, 1 \mathrm{nW} / \mathrm{cm}^{2}=0.001 \mu \mathrm{W} / \mathrm{cm}^{2}=10 \mu \mathrm{W} / \mathrm{m}^{2}$

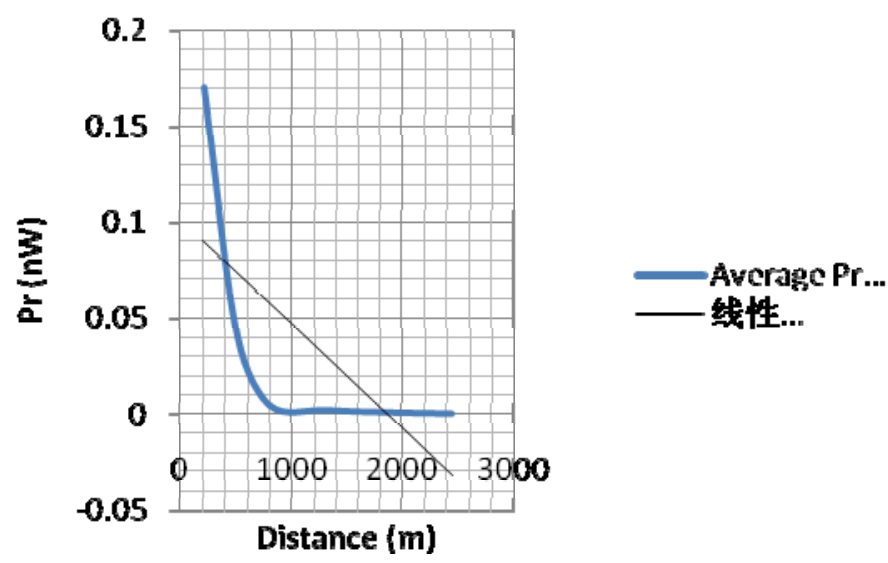

Figure 3. Graph of Received Power against Distance from cell-A BS for scenario 1

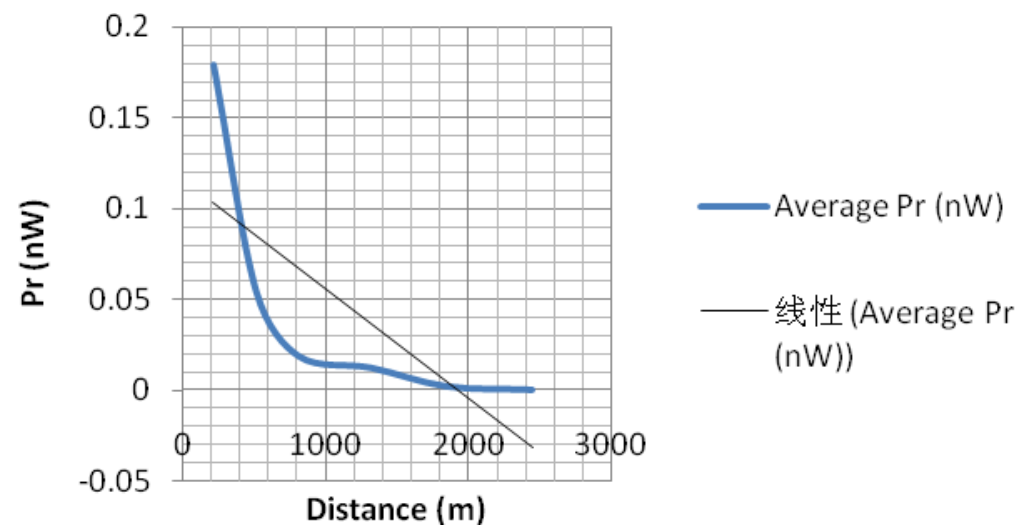

Figure 4. Graph of Received Power against Distance from cell A BS for scenario 2 


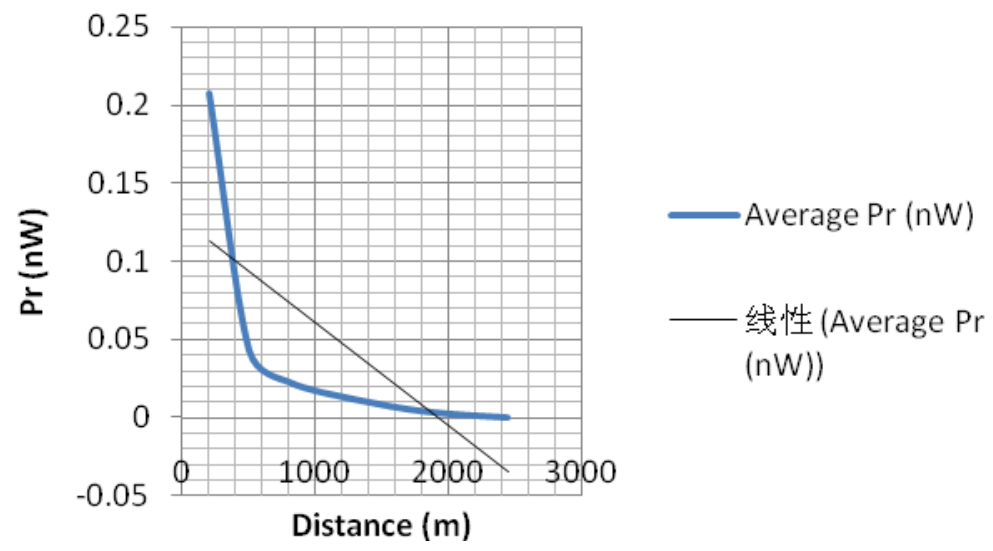

Figure 5. Graph of Received Power against Distance from cell-B BS at scenario 1

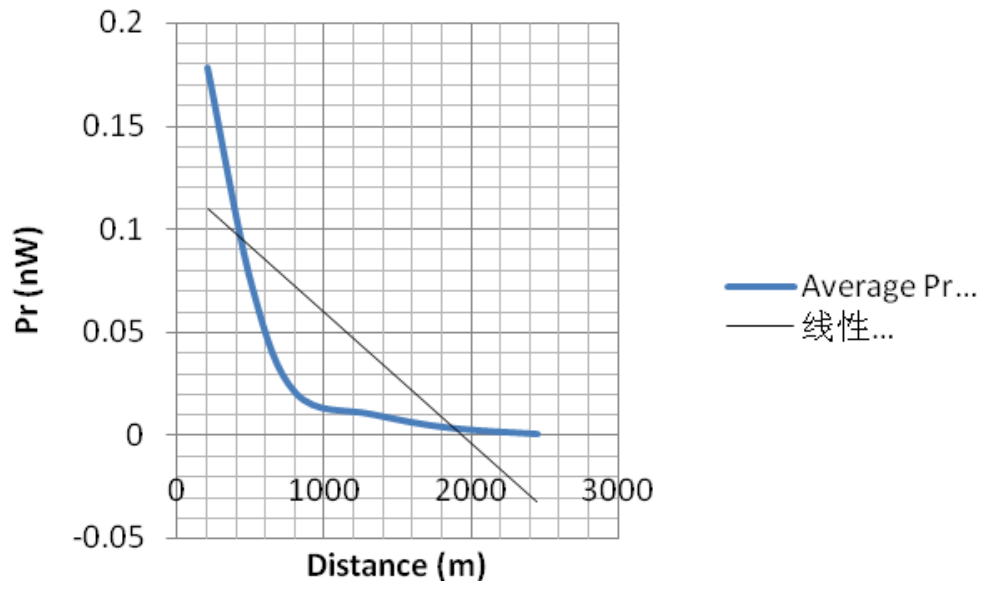

Figure 6. Graph of Received Power against Distance from cell-B BS for scenario 2

Tables 5 and 6 show the radiation calculated by multiplying the received signal power at a particular distance by the possible human area at that point.

Table 5. Radiation level from Cell-A BS

\begin{tabular}{|l|l|l|l|l|l|l|}
\hline \multirow{2}{*}{ Area $\left(\mathbf{c m}^{2}\right)$} & \multicolumn{6}{l|}{ Radiation $\left(\mathbf{n W} \mathbf{c m}^{2}\right)$} \\
\cline { 2 - 7 } & $\mathbf{0 . 1 7 1 n W}$ & $\mathbf{0 . 0 4 0 6 n W}$ & $\mathbf{0 . 0 0 4 3 n W}$ & $\mathbf{0 . 0 0 1 9 6 n W}$ & $\mathbf{0 . 0 0 0 8 1 n W}$ & $\mathbf{0 . 0 0 0 1 1 n W}$ \\
\hline $\mathbf{3 2 0 . 1 2}$ & 54.74 & 13.00 & 1.38 & 0.63 & 0.26 & 0.04 \\
\hline $\mathbf{8 4 2 . 8 0}$ & 144.12 & 34.22 & 3.62 & 1.65 & 0.68 & 0.09 \\
\hline $\mathbf{1 0 9 4 . 3 4}$ & 187.13 & 44.43 & 4.71 & 2.14 & 0.89 & 0.12 \\
\hline $\mathbf{1 2 7 6 . 7 0}$ & 218.32 & 51.83 & 5.49 & 2.50 & 1.03 & 0.14 \\
\hline $\mathbf{1 5 1 8 . 9 2}$ & 259.74 & 61.67 & 6.53 & 2.98 & 1.23 & 0.17 \\
\hline $\mathbf{1 7 3 4 . 0 0}$ & 296.51 & 70.40 & 7.46 & 3.40 & 1.40 & 0.19 \\
\hline
\end{tabular}


Table 6. Radiation Level from Cell-B BS

\begin{tabular}{|l|l|l|l|l|l|l|}
\hline \multirow{2}{*}{ Area $\left(\mathbf{c m}^{2}\right)$} & \multicolumn{6}{l}{ Radiation $\left(\mathbf{n W} \mathbf{c m}^{2}\right)$} \\
\cline { 2 - 7 } & $\mathbf{0 . 2 0 7 n W}$ & $\mathbf{0 . 0 4 3 n W}$ & $\mathbf{0 . 0 2 2 8 n W}$ & $\mathbf{0 . 0 1 1 5 n W}$ & $\mathbf{0 . 0 0 3 9 n W}$ & $\mathbf{0 . 0 0 0 2 n W}$ \\
\hline $\mathbf{3 2 0 . 1 2}$ & 66.26 & 13.77 & 7.30 & 3.68 & 1.25 & 0.06 \\
\hline $\mathbf{8 4 2 . 8 0}$ & 174.46 & 36.24 & 19.22 & 9.69 & 3.29 & 0.17 \\
\hline $\mathbf{1 0 9 4 . 3 4}$ & 226.53 & 47.07 & 24.95 & 12.58 & 4.27 & 0.22 \\
\hline $\mathbf{1 2 7 6 . 7 0}$ & 264.28 & 54.90 & 29.11 & 14.68 & 4.98 & 0.26 \\
\hline $\mathbf{1 5 1 8 . 9 2}$ & 314.42 & 65.31 & 34.63 & 17.47 & 5.92 & 0.30 \\
\hline $\mathbf{1 7 3 4 . 0 0}$ & 358.94 & 74.56 & 39.54 & 19.94 & 6.76 & 0.35 \\
\hline
\end{tabular}

Figure 7 illustrates the rate of occurrence of the various health problems in human body taken from the people living within 300 meters from the base station transmitters. Figure 8 illustrates the occurrence of the ill-health issues arranged by ages of the people living within the 300 meters radius from the BS transmitters.

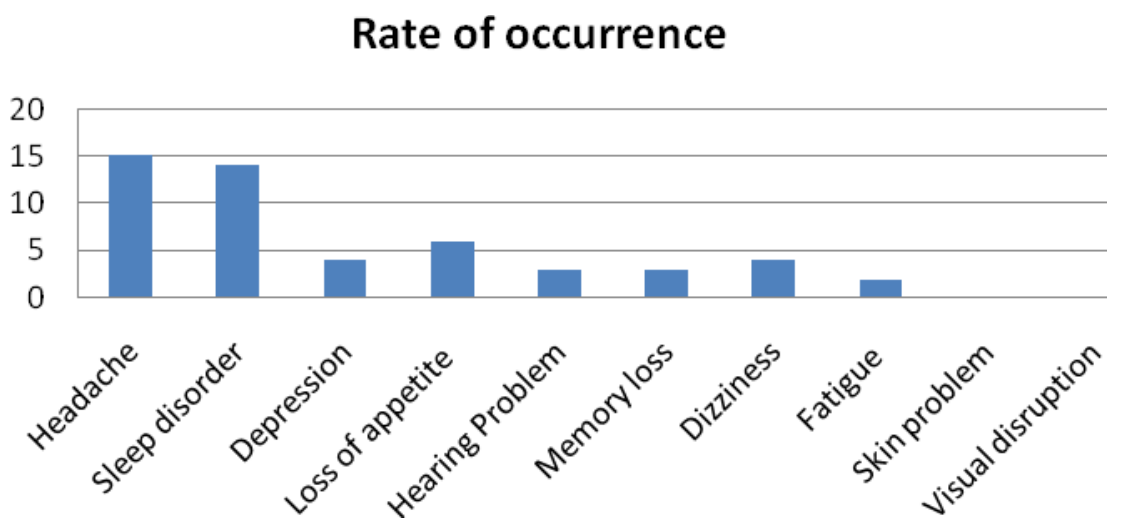

Figure 7. The rate of occurrence of Health problems in human

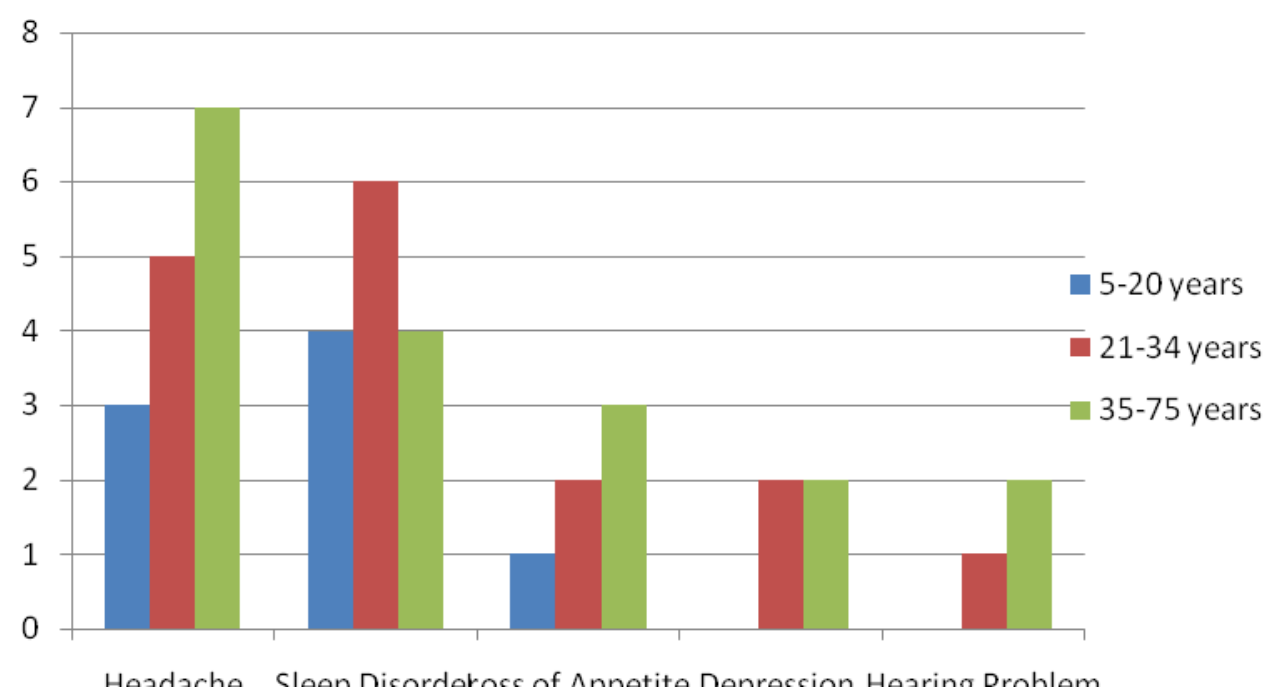

Figure 8. Ill-health rates by human ages 


\subsection{Observations}

The graph of the signal power received against distance from the BS is close to linear from $50 \mathrm{~m}$ to about $500 \mathrm{~m}$ with high values. However, from $500 \mathrm{~m}$ and above from the BS, the signal power density is maintained within a lower level as it reduces gradually to zero as the distance increases. Figures 3 to 6 show that from $50 \mathrm{~m}$ to $300 \mathrm{~m}$, the signal power density is very high and above which can cause various degrees of ill-health to people leaving within such radius as suggested in Bio-initiative report. Power densities from the different base stations from 0 to 210 meters generated the highest radiations on human body which increases with the increase of the human body area.

The occurrence of headache was observed to record the highest number, followed by the rate of occurrence of sleep disorder. Skin problems, visual disorders and other ill-health such as cardiovascular disorder where not recorded because the people did not answer questions on them. People between the ages 35 to 75 years recorded the highest number of headache illness and the people between the ages of 5 to 20 recorded the lowest number of the illness. However, people between the ages of 21 to 34 years recorded the highest number of sleeping disorder. There was a low number of hearing disorders recorded with the people between the ages of 35 to 75 having the highest record of 2 followed by the people between the ages of 21 to 34 years recording only 1 , but people between the ages of 5 to 20 years recorded nil.

The distance from the BS transmitter is a major factor that determines the level of radiation absorbed by the human body. The closer the distance of human body from the BS transmitter, the higher the rate of radiation absorbed by the body and the higher the possibility and occurrence of illness.

\section{Conclusion}

The investigation on the implications of electromagnetic radiation from telecommunication base stations to human body was successfully carried out and base on the results and the analysis of the research, it was confirmed that the radiated power density measured was high from 0 to $210 \mathrm{~m}$ distance from the BS transmitter. The level of electromagnetic radiation absorbed was confirmed to be very high within $300 \mathrm{~m}$ distance from BS transmitter with measured power density of $0.207 \mathrm{nW}$ and higher closer the BS. Therefore, it will not be safe to reside within $300 \mathrm{~m}$ radius from the BS transmitters considering the present transmitting power density level.

From the health result it was confirmed that people living within $300 \mathrm{~m}$ distance from the BS transmitter suffered different types of ill health with the rate of occurrence of headache recording highest within the ages of 35 to 75 years and lowest within the ages of 5 to 20 years. Sleeping disorder was confirmed to follow headache in the rate of occurrence and recorded highest within the ages of 21 to 31 years. The occurrence of other health issues such as loss of appetite, depression and hearing problems was confirmed. It was concluded that within the distance of $300 \mathrm{~m}$ from the BS transmitter, the level of radiation absorbed will have a negative effect on the human body which may result to ill health issues with time. 


\subsection{Recommendations}

It was recommended that there should be public awareness campaign on the possible negative effects of electromagnetic radiation from the cellular mobile radio transmitters which is absorbed by the human body and the possible ways to avoid the resulting harm. The national telecommunication agencies should make and implement a policy to ensure that the erection of BS transmitters is made from $300 \mathrm{~m}$ distance away from human residence and the already erected transmitters that fall within $300 \mathrm{~m}$ from human residence should reduce the radiated power density. The agencies should also ensure that people do not build new houses within $300 \mathrm{~m}$ distance from the BS transmitters.

\subsection{Further Work}

Medical test research should be carried out on the people living within $500 \mathrm{~m}$ from the transmitting base stations and other electrical and electronic devices such as transformers etc. This would provide more concrete evidence of the harmful effects of the electromagnetic radiation. Also further research should be made on the effect of the electromagnetic radiations on other living things in our environment such as the birds and other animals.

\section{References}

CCOHS. (2012). Microwave Ovens and their Hazards. [Online] Available: http://www.ccohs.ca/oshanswers/phys_agents/microwave_ovens.html\#_1_3 (November 22, 2013)

Eger H., Hagen K. U., Lucas B., Vogel P., \& Voit H. (2004). The Influence of Being Physically Near to a Cell Phone Transmission Mast on the Incidence of Cancer, Published in Umwelt·Medizin·Gesellschaft.

[Online] Available: http://www.powerwatch.org.uk/news/20041118_naila.pdf (August 12, 2013)

FU T. et al, (2010). Preliminary Report on the Indoor Electromagnetic Radiation in a Municipality of Western P.R. China: up-to-now Still within the Range, Journal of Engineering and Technology

Girish K., (2010). Radiation Hazards from Cell Phones/ Cell Towers. [Online] Available: http://apps.fcc.gov/ecfs/document/view?id=7520940951 (August 7, 2013)

Halim B. Abdullah K., \& Gürcan Y. (2009). Natural Background Radiation Measurements of a Base Station in Yalvaç County, Journal of Arts and Sciences Sayı

ICNIRP (1998). International Commission on Non-Ionizing Radiation Protection Guidelines for limiting exposure to time-varying electric, magnetic, and electromagnetic fields (up to $300 \mathrm{GHz}$ ), Health Phys, 74, 494-522. [Online] Available: http://www.icnirp.de/documents/emfgdl.pdf (November 22, 2013)

Jon W. M, Weihava Z. (2003). Wireless communication and networking, Prentice Hall

Koprivica M., et al., (2013). Statistical Analysis of Electromagnetic Radiation Measurements in the Vicinity of GSM/UMTS Base Station Antenna Masts. [Online] Available: 
http://rpd.oxfordjournals.org/content/early/2013/09/19/rpd.nct230.abstract (December 26, 2013)

Kovach S. (2007). The Hidden Dangers of Cell Phone Radiation, Life Extension Magazine. [Online] Available: http://www.lef.org/magazine/mag2007/aug2007_report_cellphone_radiation_01.htm(Novemb er 22, 2013)

Liu B., Beghou L, \& Pichon L. (2008). Adaptive Genetic Algorithm Based Source Identification with Near-Field Scanning, Progress in Electromagnetic Research B., 9, pp. 215-230. http://dx.doi.org/10.2528/PIERB08070904

Mohana P. S. (2002). Introduction to Wireless Systems, Johan Wiley \& Sons, INC.

Mousa A. (2011). Electromagnetic Radiation Measurements and Safety Issues of some Cellular Base Stations in Nablus. Journal of Engineering Science and Technology Review, 4(1) $35-42$.

Oberfeld, G. et al. (2004). The microwave syndrome-further aspects of a Spanish study. Biological Effects of EMFs, Kos Greece. [Online] Available: http://www.powerwatch.org.uk/pdfs/20040809_kos.pdf (November 22, 2013)

Rakesh K.B.(2013). Electro Magnetic Field (EMF) Radiation from Mobile Towers \& Handsets. [Online] Available: http://www.itu.int/en/ITU-T/climatechange/emf-1305/Documents/Presentations/s2part2p3-R KBhatnagar.pdf (January 2, 2014)

Sabah H.S. (2013). Study of the Cell Towers Radiation Levels in Residential Areas, Proceedings of the 2013 International Conference on Electronics and Communication Systems

Santini R, Santini P, Danze JM, Le Ruz P, \& Seigne M, (2002). Study of the health of people living in the vicinity of mobile phone base stations: Incidence according to distance and sex, Pathology Biology, 50(6), 369-73, 2002 27. [Online] Available: http://www.bevolution.dk/pdf/SantiniEnglishBevolution.pdf (November 22, 2013)

Sujoy K.G. et al. (2011). Cell Phone Towers Radiation Hazards. [Online] Available: http://www.ee.iitb.ac.in/ mwave/Cell-tower-rad-report-WB-Environ-Oct2011.pdf (December $26,2013)$

Theodore S. R. (2002). Wireless Communications, Principles \& practice, $2^{\text {nd }}$ edition, Prentice Hall

Wiki, (2014). Mobile Phone Radiation and Health. [Online] Available: http://en.wikipedia.org/wiki/Mobile_phone_radiation_and_health (January 5, 2013)

Wikipedia (2012). Electromagnetic Radiation. [Online] Available: http://en.wikipedia.org/wiki/Electromagnetic_radiation (August 12, 2013)

Wolf R, Wolf D. (2004). Increased Incidence of Cancer near a Cell-phone Transmitter Station 
(Israel), International Journal of Cancer Prevention, 1(2). [Online] Available: http://home.scarlet.be/ tsf94646/001/documents/INCREASED\%20INCIDENCE\%20OF\%20 CANCER\%20NEAR\%20A\%20CELL.pdf (November 22, 2013) 